\title{
Perspectives on botanical research publications in South Africa: an assessment of five local journals from 1988 to 2002, a period of transition and transformation
}

\author{
C.L. Bredenkamp ${ }^{a \neq}$ and G.F. Smith
}

\begin{abstract}
South Africa has every right to take pride in its rich and unique botanical diversity. As part of investigating the discipline of botany in the country, we have assessed the contents of five botany-related South African journals in the period 1988-2002, analysing the sub-disciplines, affiliations of the contributors, and the age, gender and race of the first authors. The results show various trends, such as a decline in the number of articles during the 1990s and then an increase in 2001 and 2002. A specific niche for each of the five journals has been identified. These journals have adopted strategies and introduced improvements to survive change in the evolving scientific environment. Most articles are from authors in the age group 31-40; men accounted for $68 \%$ of botanical papers and women $32 \%$. Whites authored $94 \%$, and other racial groups $6 \%$. The botanical sciences are among the leaders in South African research publications in terms of output and citations.
\end{abstract}

\section{Introduction}

Interest in South African botany has long been driven by the natural environment and rich plant diversity of the country. ${ }^{1}$ The Genera of South African Plants by W.H. Harvey is reputed to be the first botanical book printed in South Africa, in Cape Town in 1838. This was followed by increasingly formally structured research on the flora of South Africa including the documentation of families, genera and species, with inventories, identification keys, field guides, detailed monographs, regional floras and Red Data lists as records and publications. Accurate coverage of the unique flora at the species level has been made possible through PRECIS (National Herbarium, Pretoria [PRE] Computerized Information System), listing approximately 368 families and 24000 taxa (species and infraspecific taxa). ${ }^{2}$ Interest in plant ecology has also been driven by the dynamics and composition of the natural environment, and several vegetation maps, together with numerous descriptions of vegetation types and plant communities have been generated. Plant physiologists have been presented with a vast range of subjects, examining physiological processes within this natural plant diversity. Structural elucidation of DNA and the genes that it encodes at molecular level has moved the emphasis in botanical research in wealthy countries to a molecular focus, with the consequent development of molecular biology, encompassing molecular biosystematics and biotechnology. These trends reached South Africa during the 1980s. In spite of our rich botanical diversity, core interest in the 'traditional' botanical sub-disciplines has

${ }^{a}$ South African National Biodiversity Institute, Private Bag X101, Pretoria 0001, South Africa.

${ }^{b}$ South African National Biodiversity Institute, Pretoria, and H.G.W.J. Schweickerdt Herbarium, Department of Botany, University of Pretoria, Pretoria 0002 South Africa.

${ }^{\ddagger}$ Author for correspondence. E-mail: bredenkamp@ sanbi.org been waning, ${ }^{3,12}$ raising concern among botanists at universities and at institutions that account for botanical research and its related services. New techniques have influenced research in all sub-disciplines of botany, emphasizing the need to keep step with advances, to be able to publish science of current relevance.

The state of botany in South Africa should be seen as part of the overall picture of the condition of science in the country. The assessment of publications can be regarded not only as a reasonable measure of scientific viability, but also as an indication of the country's research enterprise. Pouris ${ }^{4}$ has used bibliometric indicators to rate the plant and animal sciences against other disciplines such as the earth sciences, chemistry, engineering, mathematics, and clinical medicine. These showed that biology is one of the strongest and most vigorous disciplines, and that South Africa's scientific strength lay conspicuously with the life sciences. ${ }^{5}$ Pouris ${ }^{6}$ notes also that by 1989 South African performance in biology had been concentrated in the 'macro' aspects (whole organisms and ecology) but predicted that major advances in biology would come from genetics, biochemistry and molecular biology (the 'micro' aspects, that had displayed high growth and commercially exploitable results elsewhere). Current research ${ }^{7}$ indicates that publication numbers decreased in molecular biology and genetics, contradicting the National Biotechnology Strategy in 2001.

In a survey of South African research periodicals published in 2000, Pouris and Richter ${ }^{8}$ concluded that South African journals were introspective, and that their reach in terms of circulation, subscriptions and indexing was limited. Foreign citation impact was generally low, and that prominent South African scientists published significant work abroad, to the detriment of the quality and standing of our local journals. As a result, government policy led to withdrawal of state funding for national scientific journals produced by the now-defunct Bureau for Scientific Publications, ${ }^{9}$ placing the financial burden of publication on the associate publishers, usually professional scientific associations, and forcing them to adopt new strategies to survive. Moreover, South African science became affected by restructuring, as well as by organizational and cultural changes in many scientific institutions. ${ }^{10,11}$ Herbert et al. ${ }^{3}$ reported in 2001 on what they termed the crisis in capacity and resources in taxonomy and systematics ${ }^{a}$ in this country. The main factors identified in that survey and relevant to our current study are:

- A long-term decline in human resource capacity. The number of taxonomists/systematists in South African museums had decreased by 35\% from 1991 to 2001.

- Lack of research funding: for example, National Research Foundation (NRF) grants, 38\% of submissions for research projects to the 'Conservation and Management of Ecosystems and Biodiversity' focus area, were rejected in 2001.

Systematics is a multidisciplinary field building on taxonomy. It produces predictive classifications and phylogenies reflective of evolutionary relationships. 
- Poor salaries in the academic sector, particularly in museums and herbaria, constitute a major financial disincentive to matriculants and graduates who might otherwise be considering a career in taxonomy or systematics.

The view that taxonomy and systematics research had reached a point where recovery and future progress were under serious threat ${ }^{12,13}$ is paradoxical. The justification for research has never been stronger than at present, and its relevance has never been greater. ${ }^{14}$ There have been numerous significant events in the botanical sciences ${ }^{15-20}$ the most far-reaching being South Africa's ratification of the Rio Declaration on Environment and Development (Convention on Biological Diversity).

\section{Procedure of the investigation}

\section{Scanning of publications}

All botanical papers that appeared in the five journals surveyed, African Journal of Range \& Forage Science, Bothalia, South African Journal of Botany, South African Journal of Plant and Soil and South African Journal of Science, were published between 1988 and 2002. Articles are classified in terms of the broad botanical sub-disciplines of taxonomy, ecology, physiology, biotechnology and biosystematics. Biotechnology and biosystematics have been treated as separate sub-disciplines, in order to assess the impact of the molecular sciences on botany. Institution, surname, age, gender and race of the first author are also documented. Institutions have been classified as SANBI (South African National Biodiversity Institute), university, international, government, and private. Although SANBI is a public entity in the Department of Environmental Affairs and Tourism (DEAT), we excluded it as a state department, to be able to identify the institute's separate contribution to botanical research in South Africa. Information on age, gender and race of first authors was provided by peer botanists, but in some cases the identity of authors could not be traced, this being the reason for missing data. Ages were grouped as follows: $20-30,31-40,41-50$, 51-60 and $61+$.

Journal impact factors for the years 2002 and 2003 were extracted from ISI Journal Citation Reports. ${ }^{21}$

\section{Results and discussion}

Detailed statistics on the journals are provided in Tables 1, 2 and 3, and in Figs A-D in supplementary material online at www.sajs.co.za

African Journal of Range \& Forage Science (Afr. J. Range For. Sci.) ranks as the leading rangeland and pastoral journal in Africa. It was the Journal of the Grassland Society of Southern Africa until 1992. Three issues are published per year. The current publisher is the National Inquiry Services Centre (Pty) Ltd (NISC), in Grahamstown. Support comes from the Grassland Society of Southern Africa, with P. Scogings of the University of Zululand as its editor. The journal publishes refereed scientific papers and research notes, as well as book reviews.

This journal is linked to the sub-discipline of ecology, particularly rangeland ecology and contributed 10 to 31 papers per annum from 1988 to 2002 . The number of physiology articles that appeared in it gradually declined from 1998 to 2002. It published a few taxonomy papers but none in biotechnology (Table 1).

Contributions from government institutions ranged between 2 and 21 per annum, also indicating a decline in the number of papers over the period 1997 to 2002. Foreign contributions to the journal are largely constant, with a definite increase in these submissions after 1995. Universities account for 3 to 15 articles per annum. The agricultural focus of this journal can explain the low number of articles from SANBI staff. Despite there being substantial agricultural expertise in the private sector, it does not contribute to the journal (Table 2).

The periodical has adopted the following survival strategies:

- Imposition of page charges.

- A focus on the discipline in an African context from 1993, when it adopted its present title. Contributions from elsewhere in Africa have subsequently increased.

- The policy change was introduced when the journal had already achieved financial autonomy, and was not affected by the withdrawal of state funding for government-subsidized journals.

- Afr. J. Range For. Sci. now makes use of electronic publication, with free access to its content. This arises from an agreement between NISC and the UK-based Ingenta, one of the world's largest collections of online journals. ${ }^{22}$ The benefits include enhanced international exposure and worldwide marketing.

Bothalia was first published in 1921 under the leadership of I.B. Pole Evans, then director of the Botanical Research Institute (BRI). ${ }^{23}$ It was named in honour of General Louis Botha, first prime minister of the Union of South Africa, also minister of agriculture until 1913. The BRI amalgamated with the National Botanic Gardens of South Africa (NBG) in 1989, and Bothalia became the house journal of the institute. Two parts, with indexes to contents, authors and subjects are published per year. The current scientific editor is G. Germishuizen.

The journal has a niche for papers in the sub-disciplines of taxonomy and ecology. Taxonomy papers have varied in number over the assessment period from 21 to 39, and ecology papers from 1 to11, per annum. The main focus is on taxonomy, ecology, anatomy and cytology. Although molecular biology is used as a taxonomic tool, there are very few systematics papers that have been based on molecular data, to date.

Contributions from SANBI staff have been the most numerous during our period of assessment, ranging between 11 and 32 per annum. Universities also use this journal consistently for publication, and their contribution has varied between 4 and 16 papers a year. The journal had a consistent record of 1 to 6 articles by foreign authors per annum. Other government institutions have contributed between 1 and 5 articles annually, and submissions from the private sector have been increasing. Except for a decline in number of papers in 1996, publication in Bothalia has been very consistent.

Bothalia is funded by SANBI, and has adopted the following measures to promote itself:

- Imposition of page charges.

- Marketing through the official SANBI website. ${ }^{24}$

- Selected articles are highlighted on the institute's website.

- Free indices to most volumes are available on request.

South African Journal of Botany (S. Afr. J. Bot.) was first published in June 1982, at a time when a number of national science journals were established under the auspices of the Bureau for Scientific Publications. S. Afr. J. Bot. amalgamated in 1984 with the Journal of South African Botany, which had a 50-year history as the in-house journal of the then-named NBG of South Africa. The format and name of the S. Afr. J. Bot was retained. From its inception, the S. Afr. J. Bot. was supported as the scientific mouthpiece of the South African Association of Botanists (SAAB). ${ }^{9,25-27}$ S. Afr. J. Bot. was published by NISC between 2001 and 2005, and by Elsevier thereafter. Currently it is an interdisciplinary journal for plant sciences, regularly supported by foreign contributors. The editor is J. van Staden of the University 
of KwaZulu-Natal in Pietermaritzburg. There have been about six issues per annum until year 2000, dropping to four issues per year thereafter, until 2002.

Taxonomic contributions have been consistently dominant between 1988 and 1999, with these papers varying between 27 and 58 per annum. There was a decline from 2000 to 2002. The number of ecology papers varied between 14 and 37 per annum during the period 1988 to 1994 , but there has been a marked decrease after 1995. Physiology papers have risen in number from 1998 to 2000. Although there is a trend in botany to move towards biotechnology and biosystematics, this is not evident from the papers under review. Statutory funding of S. Afr. J. Bot. was withdrawn in 2000, and a temporary decline in the number of papers arose possibly from a loss of financial support. Nevertheless, the number of papers increased again in 2001 and 2002.

The S. Afr. J. Bot. has been a favoured journal for universities, the source of 19-71 papers per annum during the assessment period. The journal has regularly published papers by foreign authors: 25 in year 2001 and 10 in year 2002. Both SANBI and other government institutions contributed 1 to 13 articles per annum. Contributions by the private sector are negligible, despite sustained research in the fields of biotechnology, weed control, horticulture and plant breeding by this sector. This trend may be linked to the issue of confidentiality that is inevitably associated with research that is directed towards commercial exploitation of intellectual property.

Strategies that have been adopted by the journal:

- It has consistently published papers by foreign authors, contributing to a high standard of content in recent years.

- On withdrawal of state funding, the S. Afr. J. Bot. became part of the NISC stable of journals, with electronic publication by Ingenta.

- The current publication by Elsevier includes the benefits of electronic publication; no page charges; rapid online publication with Articles in Press; free use of colour; electronic archiving; 30\% discount on Elsevier books; a large, worldwide readership; contents alerting services that are globally distributed; personalized citation alerts on Science Direct; worldwide marketing and exhibitions; author services and support with Author Gateway.

South African Journal of Plant and Soil (S. Afr. J. Plant Soil). The present title changed from Crop Production in 1983. It has incorporated both Applied Plant Science and Journal of the Southern African Society for Horticultural Sciences. It is published in collaboration with the South African Society of Crop Production, the Soil Science Society of South Africa, the Southern African Weed Science Society, the Southern African Plant Breeders' Association and the Southern African Society for Horticultural Sciences. Forum Press International is the publisher and there are four issues per year. The scientific editor is V. Tolmay of the Agricultural Research Council's Small Grain Institute in Bethlehem (J.B.J. van Rensburg was editor during this survey). The journal publishes refereed papers, short communications, book reviews, comments on papers recently published and, in exceptional cases, reviews on research in the fields of soil science and applied plant science.

The S. Afr. J. Plant Soil fills a unique niche in South Africa, delivering the published output from five scientific societies. The botanical papers that we have assessed from this journal indicate a trend towards the applied sub-disciplines. Most were in physiology, ranging from 4 to 19 per annum. Fewer ecology papers were published, numbers ranging from 1 to 7 . The number of taxonomy papers, mostly descriptive, was small. Papers in the molecular sciences have been evident, and biotechnology papers have featured regularly since 1998.

Government institutions are the largest contributors of botanical papers to the journal, the source of 2-19 papers a year. Universities have contributed 3-12 articles. Papers by foreign authors have been erratic, at two or fewer annually. There have been only a few contributions from the private sector. The absence of contributions by SANBI is attributed to the applied nature of the journal content.

Strategies adopted by the journal have been:

- Imposition of page charges.

- It is published jointly by the five professional societies. Cooperation between these societies with respect to journal consolidation is a strategy that aims at a larger botanical community, while cutting costs.

- These societies have provided an institutional website for electronic publication.

South African Journal of Science (S. Afr. J. Sci.). This bimonthly periodical is published by the Academy of Science of South Africa ${ }^{28,29}$ with G.S. Baker as editor. It was established by the South (now Southern) African Association for the Advancement of Science $\left(\mathrm{S}_{2} \mathrm{~A}_{3}\right)$ in 1903. After four decades of annual volumes, monthly issues were introduced in $1947 . .^{30}$ The S. Afr. J. Sci. is a multidisciplinary journal, broadly reflecting South Africa's scientific activity. ${ }^{28}$ Noting the multidisciplinary nature of the S. Afr. J. Sci., we have assessed the papers in ecology at 5 to17 per annum. Taxonomy papers have varied from 3 to 17 and physiology from 2 to16. Three biosystematics papers were published during 1988 to1993, and the trend in the number of biotechnology papers increased between 1998 and 2002.

The journal reflects a balance of various institutions that regularly contribute botanical papers. But for a slight decline in papers from 1997 to 1999, universities have constantly contributed between 11 and 29 botanical papers per annum. Government institutions have published 2 to 9 papers a year. Initial contributions from SANBI were relatively few, but 1 to 7 papers per annum have been published since 1992. Foreign authors contributed 1 to 22 papers from 1993 to 2002, and the private sector has also made a notable contribution.

- The journal is now funded by the Department of Science and Technology through the Academy of Science of South Africa (ASSAf). ${ }^{28,29}$

- Partial page charges generate additional funding.

- This journal has enjoyed the advantages of electronic publication through SABINET Online and SA ePublications. ${ }^{31}$

Our survey indicates that each of the assessed journals has its own niche. Afr. J. Range For. Sci. favours applied ecology papers, whereas Bothalia publishes papers on taxonomy and ecology. S. Afr. J. Bot. is interdisciplinary, showing a gradual decline in the number of taxonomy and ecology papers and a notable increase in the number of physiology papers over the assessment period. The currently growing interest in ethnopharmacology, biosystematics and biotechnology has pressed this journal to publish more contributions in these fields. The S. Afr. J. Plant Soil tends towards the applied sub-disciplines, especially physiology.

\section{Number of botanical articles published in the five}

\section{South African journals from 1988 to 2002}

Taxonomy made the largest contribution to the body of botanical publications, followed by ecology (see Fig. A online). These trends are because many universities, SANBI, and private and government organizations (especially those serving nature conservation and agriculture) focus on these sub-disciplines. Fewer 
physiology papers should be seen in context with the application of this sub-discipline, together with trends towards biotechnology, implying publication in specialized journals. Although molecular biology has attracted some of the best students, as well as improved funding, ${ }^{32}$ there were only a few research papers in this field appearing in South African journals during the assessment period. Articles in this sub-discipline from a South African address are likely to appear in foreign applied physiological and biotechnology journals.

Botanical publications peaked in number between 1988 and 1990 (Fig. B online). A decline followed in 1991 and in the mid-1990s. We reason that many botanists pursued contract and consultation work, either through lack of full-time employment or to supplement their income, and this activity does not generate open publications. A decline in the number of papers in 2000 could be the consequence of withdrawal of government funding from the BSP and the national scientific journals. The number of papers increased in 2001 and 2002 after the demise of the BSP, but did not reach the levels achieved in 1988-90. Current research shows a substantial increase in the number of publications in the plant and animal sciences during the period 1995-2005.

Age and gender of contributors to the five South African journals between 1988 and 2002

Figure $C$ indicates numerical trends with gender of authors, grouped according to age at publication. The survey period covers 15 years, and because productive authors contribute regularly over their careers, the best depiction is by reflecting author's age at publication date. Most articles are from the age group 31-40, with a decline in output from the 41-50, 51-60 and $61-75$ age groups. At age $20-30$, women published more papers than men. Numbers of papers remain about constant up to the 51-60 age group, from which we conclude that women in botany are not forsaking careers for family commitments. Men generally have an extended continuity in their careers, at a peak for age group 31-40, with a decline in output thereafter. The number of papers by women in the 61-75 age group only slightly exceeds that by men.

A 2002 survey showed that $83 \%$ of all South African research papers come from men, and $17 \%$ from women. ${ }^{33}$ Our analysis indicates that men generate about $68 \%$ of botanical papers (1223/1787), while women account for 32\% (654/1787). We attribute the difference between the numbers of papers by men and women to traditional views on careers for women. Fewer female scientists probably arise from responsibilities such as parenthood. The situation has been partially addressed by government policies on employment equity and remuneration, as well as by provision of maternity and compassionate leave. The percentage of papers from female botanists during the report period was almost double that from women in other scientific disciplines. Blankley and $\mathrm{Kahn}^{34}$ have examined the demographic profile of South African researchers in 2004, and found that women comprised $35 \%$ of all researchers (compared with $49 \%$ in Argentina, 44\% in Russia, 28\% in Norway and 11\% in Japan).

Our survey shows that $94 \%$ (2335/2482) of botanical papers, published from 1988-2002, come from white scientists, with other racial groups authoring $6 \%$ of the rest. The greatest proportion of scientific articles recorded by the South African Knowledgebase (SAK) and published in the years 1990-98 originated from white academics ( $94 \%$ approximate average), which is in close agreement with our result. ${ }^{33}$

\section{Bibliometric analysis}

We used ISI Journal Citation Reports (JCR) ${ }^{21}$ for comparison of selected South African botanical journals with other national and foreign journals. ${ }^{35,36}$ Of the five local journals assessed, Afr. J. Range For. Sci. and S. Afr. J. Plant Soil were not indexed in the JCR for 2002 or 2003, but had impact factors in 1996 of 0.279 and 0.063 , respectively. ${ }^{8}$ At this time the S. Afr. J. Sci., S. Afr. J. Bot. and Bothalia were the only three South African journals publishing botany that were indexed in JCR.

The three journals mentioned above are compared with other periodicals in the biological disciplines, as the scope of South African journals that publish botany is limited (Table 3). Journals used in the analysis were African Entomology (Afr. Entomol.), African Zoology (Afr. Zool.), South African Journal of Animal Science (S. Afr. J. Anim. Sci.), South African Journal of Marine Science [S. Afr. J. Mar. Sci.; which changed its title in 2003 to African Journal of Marine Science (Afr. J. Mar. Sci.)] and South African Journal of Wildlife Research (S. Afr. J. Wildl. Res.).

Summary of results:

- S. Afr. J. Sci. scored 1397 citations, followed by the S. Afr. J. Mar. Sci. with 915 (Afr. J. Mar. Sci. 58). The number of citations for the two botanical journals S. Afr. J. Bot. (445) and Bothalia (286) were higher than the other South African journals, with values ranging from 39 to 232 .

- The number of articles published in 2003 are S. Afr. J. Sci., 89; S. Afr. J. Bot. and Afr J Mar Sci., 49. All the other journals published 15-39 articles per annum.

- Of the eight selected South African journals, six had impact factors above 0.3; that of the S. Afr. J. Sci. was 0.93 and that of Afr. J. Mar. Sci., reached 0.89 .

- Afr. J. Mar. Sci. had the highest immediacy index (1.184) (citations to current articles/number of current articles). The immediacy indices of the two botanical journals S. Afr. J. Bot. (0.469) and Bothalia (0.067) as well as that of S. Afr. J. Sci. (0.124) exceeded those of most other selected journals in the biological disciplines, these ranging from 0 to 0.059 .

- Cited half-life values of 10 or more are given for Bothalia, S. Afr. J. Bot., Afr. J. Mar. Sci. and S. Afr. J. Wildl. Res., implying that there is a stretch of 10 or more years over which $50 \%$ of the journal's articles have accumulated citations, covering years 1993 to 2003 .

Table 3 reflects relatively low immediacy indices for journals publishing in classical taxonomy. The published information in taxonomy is of global importance, and the description of specific taxa has long-term significance but does not tend to attract immediate citation. When reference to a scientific name of a plant is made, it is customary to cite, within the text, the author(s) that are responsible for the nomenclature. Since such citation does not appear in appended references at the end of papers, it is not reflected in citation analyses.

The cited half-life is the age-range of half of the cited articles of a journal. If the half-life is relatively long, it implies an extended relevance of the published material, which is the case in plant taxonomy.

\section{Comparison of selected South African journals, publishing botany, with foreign journals (Table 3 )}

The South African journals were benchmarked by comparing them with foreign peer journals that commonly publish articles in all sub-disciplines of botany (Fig. D online). The latter used in the analysis were American Journal of Botany (Am. J. Bot.), Australian Journal of Botany (Aust. J. Bot.), Botanical Journal of the Linnean Society (Bot. J. Linn. Soc.), Botanical Review (Bot. Rev.) and Canadian Journal of Botany (Can. J. Bot.).

The Am. J. Bot. records the largest total citations, together with number of articles, and the highest impact factor (2.37). Bot. Rev. scored the second-highest impact factor of 1.82 (number of 
citations at 1329/number of articles at 12). By contrast, in 2003 , both Bothalia (286 citations/15 articles) and S. Afr. J. Bot. (445 citations/49 articles) had impact factors below 0.5 . The impact factor is raised by an elevated numerator (the number of citations to recent articles), or by a depressed denominator (the number of recent articles included). In practice, both Bothalia and S. Afr. J. Bot. have played a major role in serving the botanical community of South Africa, and have published more articles per individual issue than Bot. Rev. Impact factors of both were lower as a consequence of the calculation method, and so give an unflattering impression in journal assessments made by science councils and potential contributors. In our experience, botanists tend to be advised, in the course of in-house performance assessments, to publish abroad, to the detriment of our local journals.

Impact factors tend to fluctuate (Fig. D): for the Am. J. Bot., it ranged from 2.066 to 2.463. The impact factors of both Aust. J. Bot. and Can. J. Bot. exceeded 1.0 in 1999, but declined to 0.9 in 2003. The impact factors of the two South African journals were the lowest during this period. Bothalia ranged between 0.176 and 0.358 and $S$. Afr. J. Bot. between 0.136 and 0.522 . The impact factor of the S. Afr. J. Sci. rose from 0.328 in 1998 to 0.930 in 2003.

The relatively low citation indices of our botanical journals is doubtless predictable, as the primary focus is South African botany. Furthermore, financial constraints have limited foreign marketing and distribution of local publications. Limited readership translates into limited citation. Lastly, our journals are perceived from abroad as being (less-significant) southern hemisphere publications, even though they report on priority issues in biodiversity, sustainability and conservation in one of the world's richest floral regions.

\section{Editorial staff}

Both Bothalia and S. Afr. J. Sci. have permanent editors and support staff, remunerated by SANBI and ASSAf, respectively. Afr. J. Range For. Sci., S. Afr. J. Bot. (until taken over by Elsevier) and S. Afr. J. Plant Soil, in contrast, are funded by their respective scientific societies, without formal remuneration of editors or support staff.

\section{Fundamental problems}

The recent history of South Africa, with a change to a democratic government in 1994, and the consequential adoption of new policies and funding practices, are identified as contributors to the decline in botanical science during the survey period; for example, by the decrease in number of taxonomists/systematists, amalgamation of journals and professional societies, and inadequate funding as mentioned above. ${ }^{3,9}$ The restructuring of higher education, and the scientific institutions, linked with the accompanying infrastructural, financial, social and work-related changes, has had a profound influence on the productivity of botanists. A large onus was placed on botanists in the mid-90s to adapt to change, but some of our best opted for emigration, leaving South Africa with a deficit of competent and qualified people in the field, a trend that may apply beyond botanical science. Others have made career changes. The decline in the number of botanical articles published during the mid-1990s (Fig. B) is identified as a direct consequence. The numbers of articles have since increased, due to adoption of new policies and an accommodation to the new dispensation.

Molecular biology and its sub-disciplines are areas of high growth and commercially exploitable potential. The current global trend towards molecular bio-research has had a profound impact on all biological disciplines, including botany. 'Rationalization' of biological disciplines has taken place at most South African universities and several are now structured together under the banner of 'Biological Sciences' or 'Schools of Environmental Sciences and Development', as examples. Funding has been channelled to molecular biology and biotechnology, resulting in students following these sub-disciplines. Although molecular biology and biotechnology have existed for years, they are poorly represented in South African journals during our period of review.

Immense challenges remain for the botanical sciences in South Africa at both the 'macro' and the 'micro' levels. A decline in the number of botany students is unaffordable, and recruitment is an absolute necessity. Career opportunites is a prime consideration when choosing a vocation and government remains the main employer of botanists. Students have believed that degrees in the molecular biosciences will guarantee permanent employment, but the reality in South Africa remains that these posts in scientific institutions and private enterprise are limited. However, with cabinet approval of the National Biotechnology Strategy for South Africa in 2001 and increased investment in modern biotechnology, expanded career opportunities are at hand. ${ }^{32}$

These structures have coerced many botanists to become self-employed after graduation. Government's latest conservation and environmental policies offer opportunities for entrepreneurship in botany, especially in ecology, undertaking environmental impact assessments, creating outputs that do not contribute to statistics covering open scientific publications. According to Herbert, ${ }^{38}$ in 2001, the NRF regarded conservation and management of ecosystems and biodiversity as areas of lesser need in the allocation of funding. The future of taxonomy can suffer further threat, with consequent impact upon future advancements in the study and the protection of biodiversity in South Africa. The growth of relevant South African journals will also be at risk. Currently, the $\mathrm{NRF}^{37}$ is hosting the South African Biosystematics Initiative (SABI) ${ }^{39}$ (embedded within the Conservation and Management of Ecosystems and Biodiversity Focus Area) aimed at enhancing the country's capacity to undertake research in biosystematics.

Our assessment of trends in South African research publications ${ }^{40}$ shows that only three disciplines have produced more than 1000 publications during the period 2000-2004. According to the ISI field categories, these are plant sciences (2182 publications), animal sciences (2108 papers) and environment/ecology (1187 articles). Moreover, an analysis of papers generated in the 1995-2005 period indicated that the combined field of plant and animal sciences was the most productive in South Africa. ${ }^{7}$ As Jeenah and Pouris point out, research publications are a proxy for scientific activity.

\section{Concluding remarks}

- Some assessed journals have failed to comply with ISI accreditation and evaluation procedures during our assessment period and some of them remain unaccredited. Current evaluation procedures should dictate ISI accreditation for all scientific journals.

- Professional societies representing the botanical community, editors of the five journals and their publishers have collectively found new strategies for their sustained existence and innovations have been implemented.

- The extent and quality of botanical articles must be continually monitored and maintained by all the assessed journals in the interest of funding for future academic publication.

- Electronic publication is now a well-established alternative or complement to print production. Access to these journals on the internet and downloading of articles should be pursued 
and promoted to increase efficiency of publication, as well as international visibility.

- Mentoring programmes are being introduced at scientific institutions, to advise young botanists on how to publish research results.

- Rated botanists need to publish their best work in South African as well as good foreign journals; these publications are increasingly available to emerging botanical scientists on the web.

- Ratification of the CBD, the Biodiversity white paper ${ }^{41}$ and the white paper on Science and Technology $y^{42}$ obliges government to address the needs of biological research. The adoption of the Biodiversity Bill on 31 May 2004 is evidence of government's commitment to the achievement of this goal.

We thank Richard Clark for his constructive role during the editing of this paper.

Received 14 November 2004. Accepted 23 October 2008.

1. Germishuizen G., Meyer N.L., Steenkamp Y. and Keith M. (Eds) 2006. A checklist of South African plants. Southern African Botanical Diversity Network Report No. 41. SABONET, Pretoria.

2. Germishuizen G. and Meyer N.L. (Eds) (2003). Plants of southern Africa: an annotated checklist. Strelitzia 14. National Botanical Institute, Pretoria.

3. Herbert D.G., Smith G.F., Hamer M.L. and Scholtz C.H. (2001). Taxonomy and systematics in South Africa: vital research facing a crisis in capacity and resources, pp. 2-17. Unpublished report to the National Research Foundation and the Department of Arts, Culture, Science and Technology, Pretoria.

4. Pouris A. (1988). Assessing basic research in South Africa. S. Afr. J. Sci. 84, 544-546.

5. Pouris A. (1989). Strengths and weaknesses of South African science. S. Afr. J. Sci. 85, 623-626.

6. Pouris A. (1996). The writing on the wall of South African science: a scientometric assessment. S. Afr. J. Sci. 92, 267-271.

7. Jeenah M. and Pouris A. (2008). South African research in the context of Africa and globally. S. Afr. J. Sci. 104, 351-354.

8. Pouris A. and Richter L. (2000). Investigation into state-funded research journals in South Africa. S. Afr. J. Sci. 96, 98-104.

9. Smith G.F. and Raper I. (2000). Producing South African Journal of Botany: current realities and future perspectives. S. Afr. J. Bot. 66, 2-6.

10. Lutjeharms J.R.E. and Thomson J.A. (1993). Commercialising the CSIR and the death of science. S. Afr. J. Sci. 89, 8-14.

11. Toerien D.F., Walters N.M., Swart D.H. and Hofmeyer H.P. (1993). Reply to Lutjeharms and Thomson: Commercialising the CSIR and the death of science? S. Afr. J. Sci. 89, 15-22.

12. Ribbink A.J. and Greenwood P.H. (1988). Whither systematics: to wax or to wither? S. Afr. J. Sci. 84, 872-873.

13. Hopkins G.W. and Freckleton R.P. (2002). Declines in the numbers of amateur and professional taxonomists: implications for conservation. S. Afr. J. Sci. 5, 245-249.

14. Smith G.F., Buys M., Walters M., Herbert D. and Hamer M. (2008). Taxonomic research in South Africa: the state of the discipline. S. Afr. J. Sci. 104, 254-256.

15. Smith G.F. (2000). Plant nomenclature into the 21st century: what happened in St Louis at the Nomenclature Section of the XVIth International Botanical Congress? S. Afr. J. Sci. 96, 5-6.
16. Smith G.F. (2001). Southern African systematics biologists forge ahead. S. Afr. J. Sci. 97, 365-366.

17. Smith G.F. (2002). Progress in southern African systematics. S. Afr. J. Sci. 98 139-140.

18. Smith G.F. (2002). The Species Plantarum Project: Flora of the World moves ahead. S. Afr. J. Sci. 98, 28-29.

19. Pillay D., Rosswall T. and Glaser G. (2002). Meeting the challenges of Agenda 21: Priorities for the science and technology community. S. Afr. J. Sci. 98, 331-333.

20. Smith G.F., Wolfson M. and Davis G. (1997). Is botany growing in South Africa? -response to Esler. S. Afr. J. Sci. 93, 317-318.

21. ISI Web of Knowledge (2003). Journal summary list. ISI Journal Citation Reports. ISI Thomson Scientific. Available at: http://jcr4.isiknowledge.com/jcr_summary_ list.pl

22. NISC Bibliographic Information and Academic Journals (2004). Ingenta. Ingenta Select. Available online at: www.nisc.co.za

23. Fourie D. (1998). The history of the Botanical Research Institute 1903-1989. Bothalia 28, 271-297.

24. South African National Biodiversity Institute (2005). About SANBI publications. Bothalia. Available online at: www.sanbi org

25. Smith G.F. (1997). Administrative procedures of the South African Journal of Botany. Forum Botanicum 34, 9, 10, 14.

26. Smith G.F. (1999). Changes in the offing for the production of the South African Journal of Botany. Forum Botanicum 36, 1 .

27. Smith G.F., Bredenkamp G.J. and Van Staden J. (1998). New editorial dispensation of the South African Journal of Botany. S. Afr. J. Bot. 64, 369-370.

28. Gevers W. (2001). The Academy of Science of South Africa is now a statutory organization. S. Afr. J. Sci. 97, 447-449.

29. Gevers W. (2003). The Academy of Science in South Africa and the South African Journal of Science. S. Afr. J. Sci. 99, 99.

30. Cooke H.B.S. (1997). S. Afr. J. Sci.: 50 years as a monthly. S. Afr. J. Sci. 93, 358.

31. Sabinet Online: SA ePublications. (2004). More details about the service. South African online journals. Available online at: www.journals.co.za/ejour

32. Pouris A. (2003). Assessing public support for biotechnology in South Africa. S. Afr. J. Sci. 99, 513-516.

33. Anon. (2002). South African Science and Technology. Key facts and figures 2002. National Advisory Council on Innovation and the Department of Arts, Culture, Science and Technology, Pretoria.

34. Blankley W. and Kahn M. (2004). South African research and development: preliminary results and indicators from the latest survey. S. Afr. J. Sci. 100, 9-11.

35. Steynberg S. (1993). Citation analysis as a method in the qualitative evaluation of research. S. Afr. J. Sci. 89, 531.

36. Griffiths C. (1992). Citation analyses - Further implications. S. Afr. J. Sci. 88, 248-249.

37. Lickindorf E. (1998). The National Research Foundation Act: the NRF: what's in store for researchers? S. Afr. J. Sci. 94, 514-516.

38. Herbert D.G. (2001). Museum natural science and the NRF: crisis times for practitioners of fundamental biodiversity science. S. Afr. J. Sci. 97, 166-172.

39. National Research Foundation (2004). Online applications for NRF funding. Focus Area Programmes. Available online at: http://nrfonline.nrf.ac.za

40. Gevers W., Hammes M., Mati X., Mouton J., Page-Shipp R. and Pouris A. (2006). Report on a Strategic Approach to Research Publishing in South Africa, pp. 1-127. Academy of Science of South Africa, Pretoria.

41. Department of Environmental Affairs and Tourism (1997). White paper on the conservation and sustainable use of South Africa's biological diversity. Govern ment Gazette 385, No. 18163

42. Department of Arts, Culture, Science and Technology (1996). White paper on science and technology: preparing for the 21st century. Pretoria.

This article is accompanied by a supplementary tables and figures online at www.sajs.co.za 


\section{Supplementary material to:}

Bredenkamp C.L. and Smith G.F. (2008). Perspectives on botanical research publications in South Africa: an assessment of five local journals from 1988 to 2002, a period of transition and transformation. S. Afr. J. Sci. 104, 473-478.

Table 1. Numbers of papers, according to the sub-disciplines of botany, published in five South African journals between 1988 and 2002.

\begin{tabular}{|c|c|c|c|c|c|c|c|c|c|c|c|c|c|c|c|}
\hline $\begin{array}{l}\text { Journal and } \\
\text { sub-discipline }\end{array}$ & 1988 & 1989 & 1990 & 1991 & 1992 & 1993 & 1994 & 1995 & 1996 & 1997 & 1998 & 1999 & 2000 & 2001 & 2002 \\
\hline \multicolumn{16}{|c|}{ Afr. J. Range For. Sci. } \\
\hline Biosystematics & 0 & 0 & 0 & 0 & 0 & 0 & 0 & 0 & 0 & 0 & 0 & 0 & 0 & 0 & 0 \\
\hline Biotechnology & 0 & 0 & 0 & 0 & 0 & 0 & 0 & 0 & 0 & 0 & 0 & 0 & 0 & 0 & 0 \\
\hline Physiology & 11 & 5 & 8 & 1 & 3 & 1 & 1 & 4 & 0 & 0 & 2 & 1 & 1 & 0 & 1 \\
\hline Ecology & 20 & 21 & 31 & 21 & 14 & 16 & 10 & 18 & 19 & 15 & 10 & 11 & 12 & 14 & 16 \\
\hline Taxonomy & 3 & 2 & 1 & 0 & 1 & 1 & 0 & 0 & 0 & 0 & 0 & 0 & 0 & 1 & 1 \\
\hline \multicolumn{16}{|l|}{ Bothalia } \\
\hline Biosystematics & 0 & 0 & 0 & 0 & 0 & 1 & 0 & 0 & 0 & 0 & 0 & 0 & 0 & 0 & 1 \\
\hline Biotechnology & 0 & 0 & 0 & 0 & 0 & 0 & 0 & 0 & 0 & 0 & 0 & 0 & 0 & 0 & 0 \\
\hline Physiology & 0 & 0 & 0 & 0 & 0 & 0 & 0 & 0 & 0 & 0 & 0 & 0 & 0 & 0 & 0 \\
\hline Ecology & 6 & 11 & 4 & 1 & 1 & 7 & 4 & 1 & 0 & 1 & 2 & 2 & 4 & 1 & 1 \\
\hline Taxonomy & 34 & 32 & 39 & 29 & 36 & 28 & 31 & 33 & 21 & 33 & 33 & 36 & 26 & 35 & 35 \\
\hline \multicolumn{16}{|l|}{ S. Afr. J. Bot. } \\
\hline Biosystematics & 4 & 4 & 1 & 0 & 0 & 0 & 0 & 2 & 1 & 0 & 3 & 1 & 3 & 0 & 1 \\
\hline Biotechnology & 0 & 0 & 0 & 0 & 0 & 0 & 0 & 1 & 2 & 2 & 0 & 2 & 0 & 0 & 4 \\
\hline Physiology & 17 & 14 & 18 & 6 & 19 & 20 & 12 & 12 & 16 & 16 & 24 & 19 & 4 & 24 & 47 \\
\hline Ecology & 26 & 17 & 19 & 17 & 18 & 37 & 14 & 12 & 10 & 7 & 8 & 12 & 3 & 13 & 9 \\
\hline Taxonomy & 45 & 56 & 54 & 27 & 46 & 34 & 32 & 31 & 40 & 58 & 30 & 34 & 11 & 25 & 19 \\
\hline \multicolumn{16}{|c|}{ S. Afr. J. Plant Soil } \\
\hline Biosystematics & 0 & 0 & 0 & 0 & 0 & 1 & 1 & 0 & 0 & 2 & 1 & 0 & 0 & 0 & 0 \\
\hline Biotechnology & 0 & 0 & 0 & 0 & 1 & 0 & 0 & 0 & 0 & 0 & 3 & 1 & 4 & 1 & 1 \\
\hline Physiology & 19 & 15 & 16 & 4 & 10 & 6 & 6 & 8 & 11 & 4 & 12 & 9 & 11 & 14 & 10 \\
\hline Ecology & 1 & 3 & 7 & 6 & 1 & 5 & 3 & 5 & 2 & 2 & 1 & 3 & 0 & 0 & 2 \\
\hline Taxonomy & 5 & 2 & 3 & 0 & 1 & 0 & 0 & 1 & 0 & 1 & 2 & 0 & 3 & 1 & 0 \\
\hline \multicolumn{16}{|l|}{ S. Afr. J. Sci. } \\
\hline Biosystematics & 2 & 0 & 0 & 0 & 0 & 1 & 0 & 0 & 0 & 0 & 0 & 0 & 0 & 0 & 0 \\
\hline Biotechnology & 1 & 0 & 0 & 0 & 1 & 0 & 0 & 1 & 0 & 0 & 4 & 0 & 2 & 1 & 1 \\
\hline Physiology & 7 & 6 & 3 & 3 & 4 & 3 & 3 & 3 & 2 & 3 & 6 & 3 & 2 & 16 & 3 \\
\hline Ecology & 15 & 15 & 8 & 11 & 11 & 16 & 16 & 16 & 16 & 11 & 16 & 5 & 10 & 17 & 14 \\
\hline Taxonomy & 13 & 12 & 8 & 5 & 3 & 7 & 12 & 9 & 17 & 5 & 6 & 6 & 13 & 17 & 11 \\
\hline
\end{tabular}

Table 2. Institutions that contributed botanical papers to five South African journals between 1988 and 2002.

\begin{tabular}{|c|c|c|c|c|c|c|c|c|c|c|c|c|c|c|c|}
\hline Journal and institution & 1988 & 1989 & 1990 & 1991 & 1992 & 1993 & 1994 & 1995 & 1996 & 1997 & 1998 & 1999 & 2000 & 2001 & 2002 \\
\hline \multicolumn{16}{|l|}{ Afr. J. Range For. Sci. } \\
\hline Private & 1 & 0 & 0 & 0 & 0 & 0 & 0 & 0 & 0 & 0 & 0 & 0 & 0 & 1 & 0 \\
\hline Government & 20 & 21 & 21 & 11 & 10 & 7 & 4 & 12 & 10 & 5 & 4 & 4 & 2 & 6 & 4 \\
\hline International & 2 & 1 & 4 & 1 & 1 & 2 & 0 & 2 & 1 & 4 & 5 & 2 & 3 & 5 & 2 \\
\hline Universities & 9 & 7 & 15 & 10 & 7 & 9 & 7 & 8 & 7 & 6 & 3 & 6 & 6 & 3 & 12 \\
\hline SANBI & 2 & 0 & 0 & 0 & 0 & 0 & 0 & 0 & 0 & 0 & 0 & 1 & 2 & 0 & 0 \\
\hline \multicolumn{16}{|l|}{ Bothalia } \\
\hline Private & 1 & 1 & 1 & 0 & 0 & 1 & 0 & 2 & 1 & 1 & 0 & 2 & 1 & 1 & 1 \\
\hline Government & 1 & 1 & 0 & 4 & 5 & 3 & 2 & 1 & 1 & 1 & 1 & 2 & 2 & 1 & 1 \\
\hline International & 5 & 2 & 2 & 2 & 1 & 0 & 1 & 3 & 2 & 6 & 4 & 4 & 2 & 2 & 2 \\
\hline Universities & 8 & 8 & 16 & 9 & 10 & 9 & 15 & 5 & 6 & 4 & 7 & 9 & 8 & 6 & 7 \\
\hline SANBI & 24 & 32 & 24 & 14 & 21 & 23 & 18 & 23 & 11 & 22 & 22 & 21 & 17 & 26 & 26 \\
\hline \multicolumn{16}{|l|}{ S. Afr. J. Bot. } \\
\hline Private & 1 & 0 & 0 & 0 & 1 & 0 & 0 & 1 & 1 & 0 & 0 & 0 & 0 & 0 & 1 \\
\hline Government & 11 & 13 & 8 & 4 & 7 & 8 & 4 & 5 & 6 & 1 & 3 & 1 & 0 & 2 & 4 \\
\hline International & 4 & 5 & 3 & 6 & 6 & 7 & 1 & 5 & 8 & 5 & 6 & 4 & 1 & 25 & 10 \\
\hline Universities & 68 & 59 & 68 & 34 & 58 & 62 & 52 & 42 & 48 & 71 & 44 & 58 & 19 & 32 & 59 \\
\hline SANBI & 8 & 12 & 12 & 6 & 11 & 13 & 1 & 2 & 6 & 7 & 12 & 5 & 1 & 3 & 6 \\
\hline \multicolumn{16}{|l|}{ S. Afr. J. Plant Soil } \\
\hline Private & 1 & 0 & 0 & 0 & 0 & 1 & 0 & 0 & 0 & 0 & 0 & 0 & 1 & 0 & 0 \\
\hline Government & 19 & 10 & 17 & 7 & 6 & 6 & 2 & 10 & 6 & 3 & 6 & 8 & 10 & 5 & 7 \\
\hline International & 1 & 0 & 2 & 0 & 1 & 0 & 2 & 0 & 0 & 1 & 0 & 1 & 0 & 1 & 0 \\
\hline Universities & 4 & 11 & 7 & 3 & 5 & 5 & 6 & 4 & 7 & 5 & 12 & 4 & 7 & 10 & 6 \\
\hline SANBI & 0 & 0 & 0 & 0 & 0 & 0 & 0 & 0 & 0 & 0 & 0 & 0 & 0 & 0 & 0 \\
\hline \multicolumn{16}{|l|}{ S. Afr. J. Sci. } \\
\hline Private & 0 & 0 & 0 & 1 & 0 & 2 & 3 & 3 & 1 & 1 & 3 & 1 & 0 & 0 & 1 \\
\hline Government & 8 & 4 & 2 & 3 & 7 & 0 & 5 & 5 & 8 & 6 & 9 & 2 & 4 & 9 & 3 \\
\hline International & 0 & 2 & 0 & 0 & 0 & 1 & 1 & 1 & 6 & 1 & 7 & 2 & 2 & 22 & 6 \\
\hline Universities & 29 & 26 & 17 & 15 & 11 & 20 & 15 & 17 & 17 & 8 & 10 & 6 & 18 & 19 & 17 \\
\hline SANBI & 0 & 1 & 0 & 0 & 1 & 3 & 7 & 3 & 3 & 3 & 3 & 3 & 3 & 1 & 2 \\
\hline
\end{tabular}


Table 3. Bibliometric analysis of selected national and foreign journals serving the biological sciences.

\begin{tabular}{|c|c|c|c|c|c|}
\hline Abbreviated journal title & Total citations, 2003 & Impact factor & Immediacy index & Number of articles, 2003 & Cited half-life (yr) \\
\hline \multicolumn{6}{|l|}{ National journals } \\
\hline Afr. Entomol. & 108 & 0.577 & 0.000 & 39 & 5.0 \\
\hline Afr. J. Mar. Sci. & 58 & & 1.184 & 49 & \\
\hline Afr. Zool. & 39 & 0.393 & 0.027 & 37 & * \\
\hline Bothalia & 286 & 0.281 & 0.067 & 15 & $>10.0$ \\
\hline S. Afr. J. Anim. Sci. & 163 & 0.143 & 0.059 & 17 & 9.6 \\
\hline S. Afr. J. Bot. & 445 & 0.462 & 0.469 & 49 & 10.0 \\
\hline S. Afr. J. Mar. Sci. & 915 & 0.892 & & 0 & $>10.0$ \\
\hline S. Afr. J. Sci. & 1397 & 0.930 & 0.124 & 89 & 9.8 \\
\hline S. Afr. J. Wildl. Res. & 232 & 0.341 & 0.000 & 19 & $>10.0$ \\
\hline \multicolumn{6}{|l|}{ Foreign journals } \\
\hline Am. J. Bot. & 8853 & 2.373 & & 192 & \\
\hline Aust. J. Bot. & 1511 & 0.938 & & 70 & \\
\hline Bot. J. Linn. Soc. & 1438 & 0.871 & & 108 & \\
\hline Bot. Rev. & 1329 & 1.824 & & 14 & \\
\hline Can. J. Bot. & 6949 & 0.948 & & 104 & \\
\hline
\end{tabular}

*Information not available

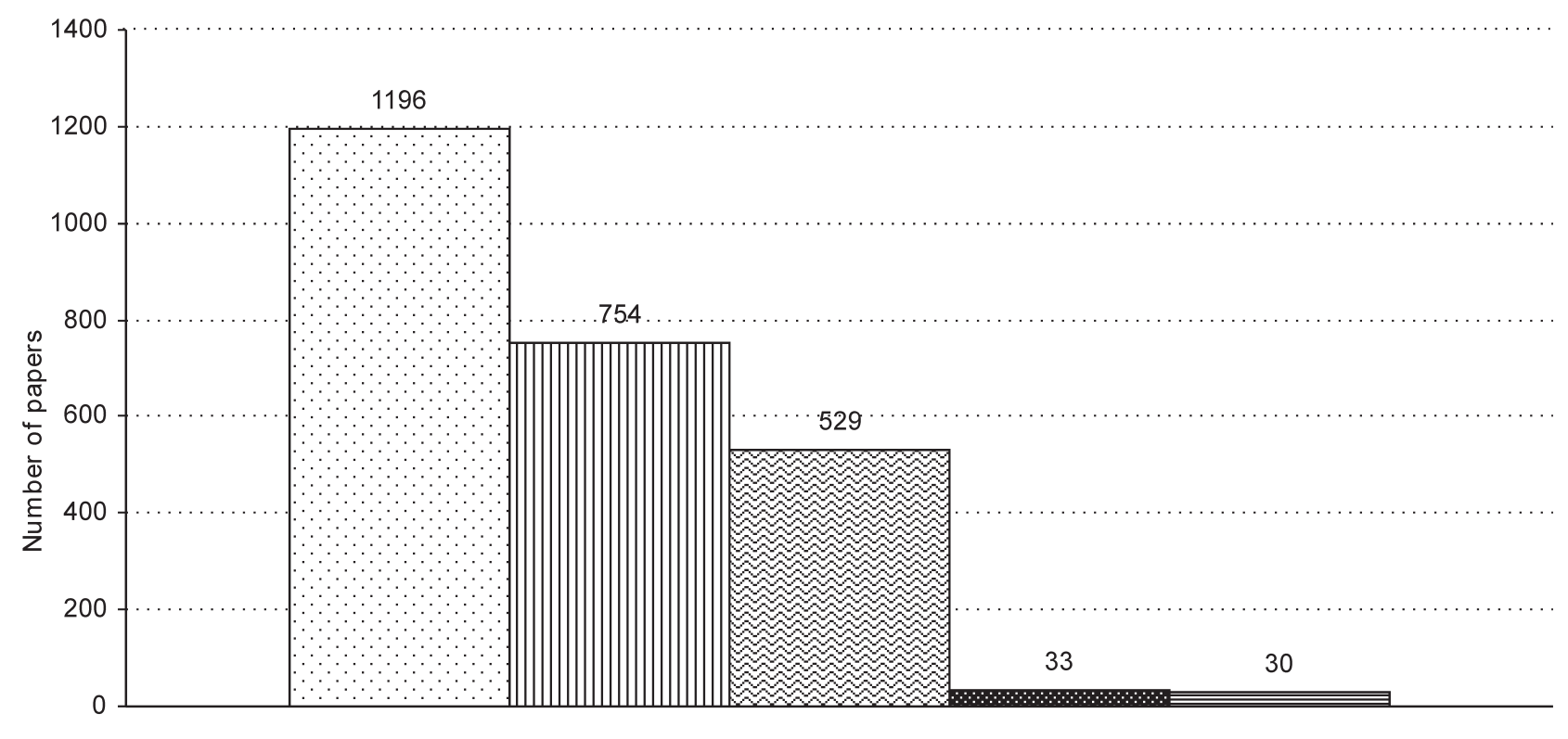

Subdisciplines

๑Taxonomy mEcology $\mathrm{g}$ Physiology Biotechnology 目Biosystematics

Fig. A. Total number of botanical papers published per sub-discipline in five South African journals from 1988 to 2002.

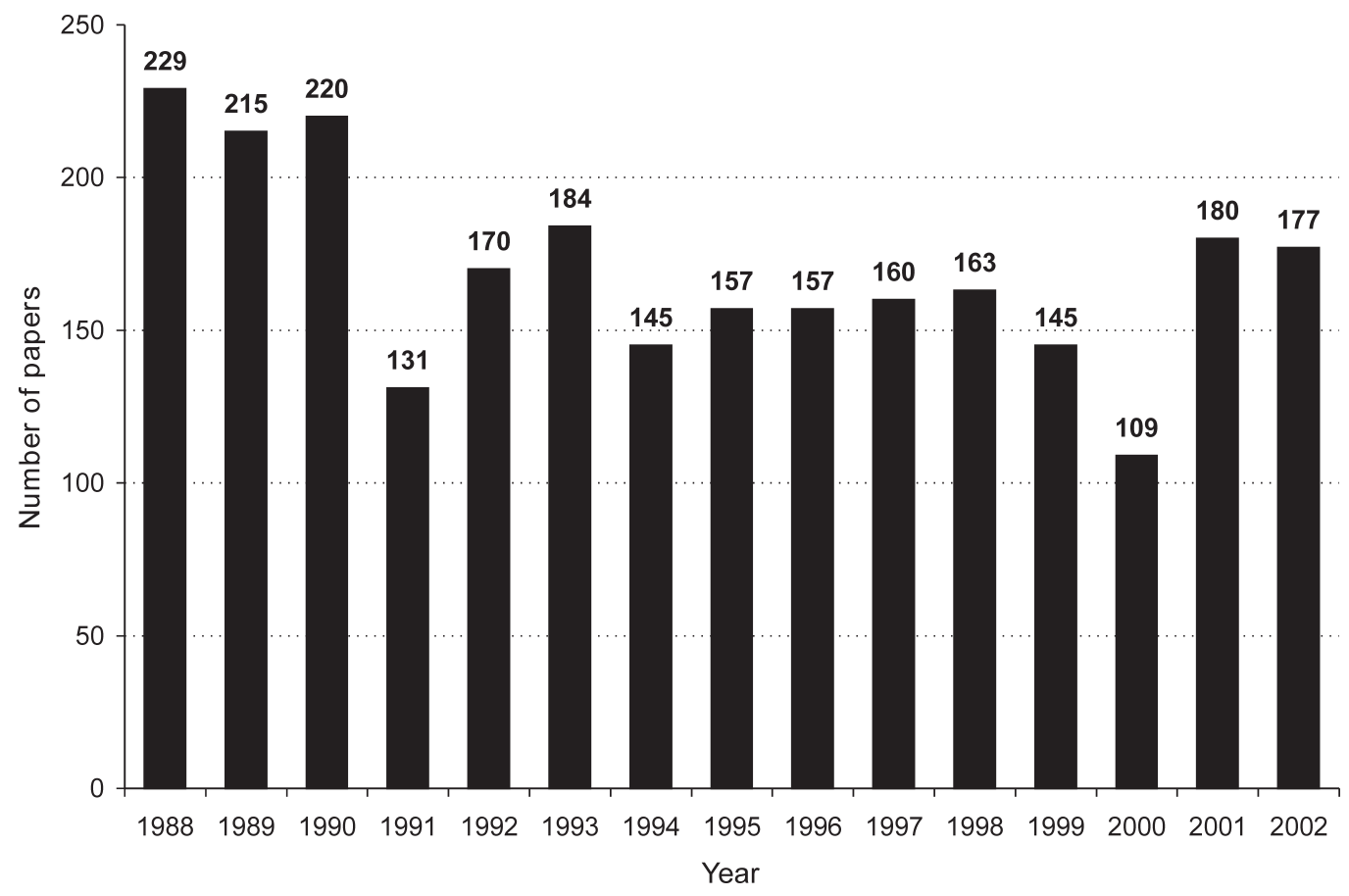

Fig. B. Number of botanical papers per year for five South African journals between 1988 and 2002. 


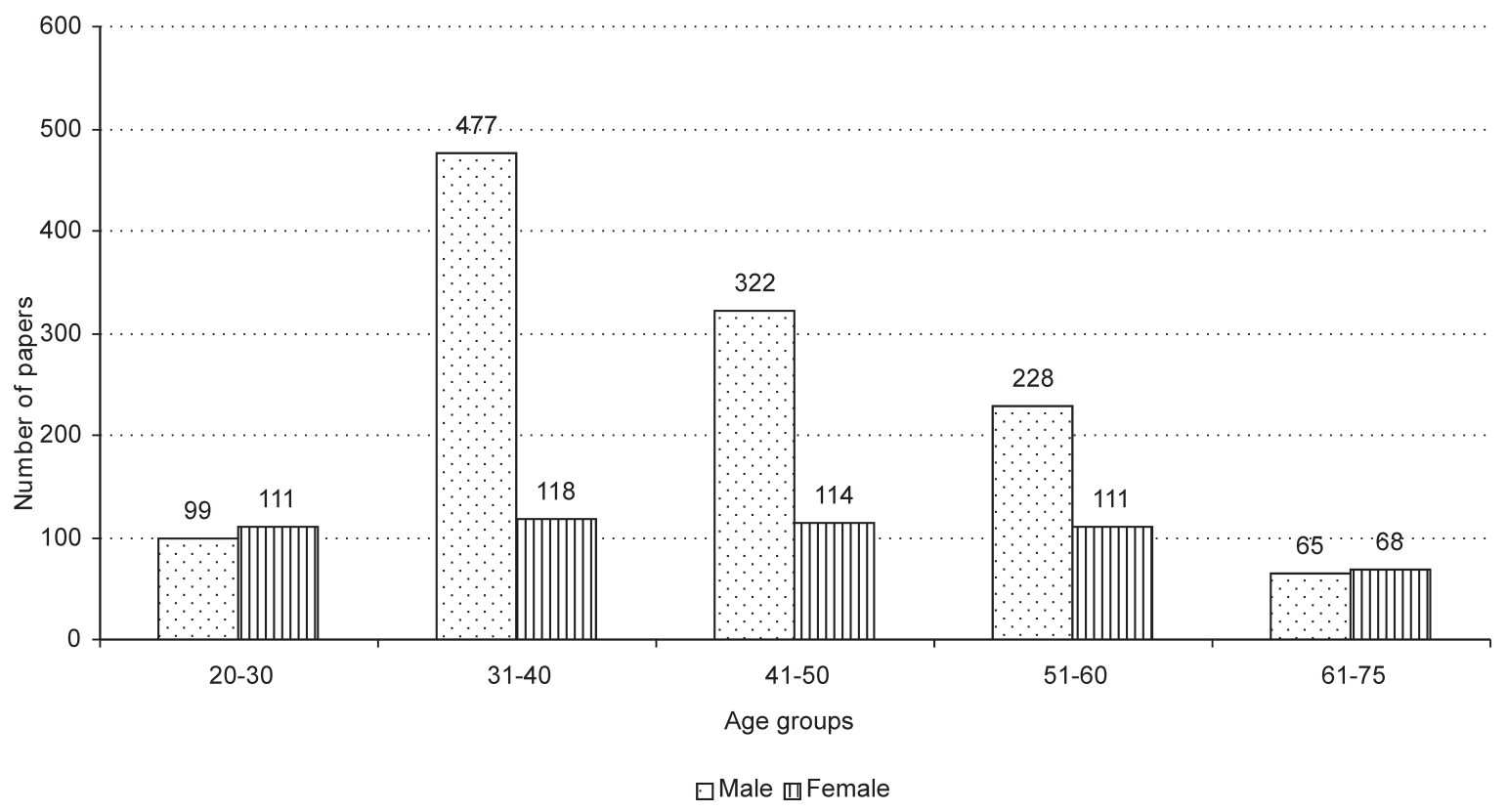

Fig. C. Gender of contributors to five South African journals between 1988 and 2002, grouped according to age at publication date.

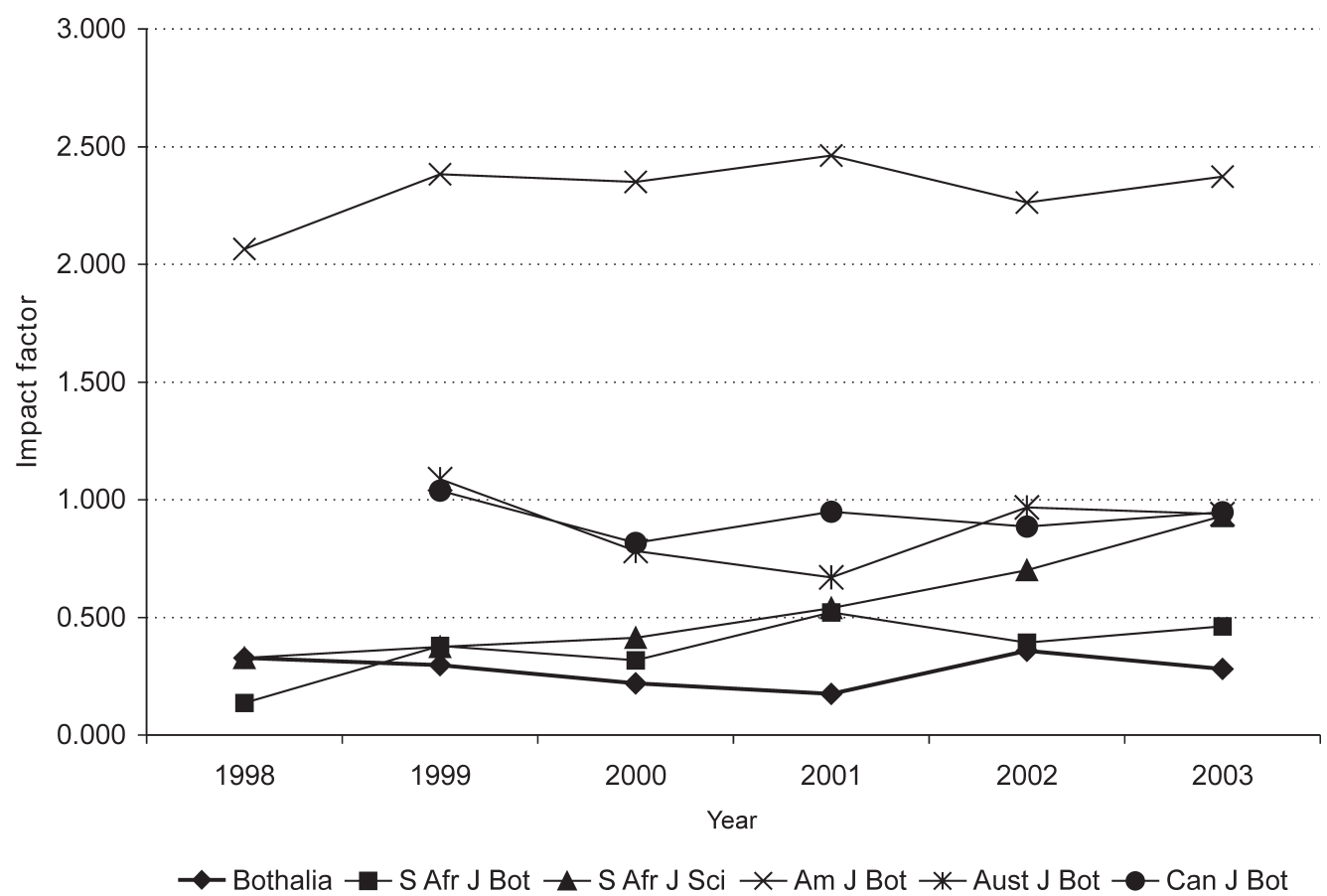

Fig. D. Impact factors of selected national and foreign botanical journals from 1998 to 2003. The S. Afr. J. Sci. is a multidisciplinary journal whose coverage includes botany. 